\title{
DEVELOPMENT OF STRUCTURED ASSIGNMENT SHEET IN REACTION RATES MATERIAL TO TRAIN SCIENCE PROCESS SKILLS
}

\author{
Eka Andini Santoso ${ }^{1}$, Suyono ${ }^{2 *}$ \\ 12 Program Studi Pendidikan Kimia, Universitas Negeri Surabaya. J1. Ketintang, \\ Surabaya 60231, Indonesia. \\ * Coressponding Author. E-mail: suyono@unesa.ac.id
}

Received: 28 Desember 2020

Accepted: 14 Juli 2021

doi: 10.29303/cep.v4i2.2312
Published: 14 Agustus 2021

\begin{abstract}
This study aims to specify the feasibility of a Structured Assignment Sheet to train students' Science Process Skills (SAS-SPS) on reaction rates material. The development research applies Research and Development (R\&D) method. This research is limited to the development phase, namely in limited testing. The SAS-SPS tested on 15 students of XI grade from SMAN 1 Arosbaya, SMAN 1 Kamal, and SMAN 2 Bangkalan who had received reaction rates material. This research conduct in December 2020. The research instruments used contain a study sheet, a validation sheet, a student response questionnaire, and science process skills test sheet. The validity obtains a percentage of content validity of $93,3 \%$ and constructs validity of $91,4 \%$, both of them have very valid criteria. Student response shows that the SAS-SPS is very practical with a percentage of $100 \%$. The effectiveness of obtaining an $\mathrm{N}$-gain score of 0,76 with a high category. It indicates that the SAS-SPS developed is feasible and suitable for use in the learning process.
\end{abstract}

Keywords: structured assignment sheet (SAS), science process skills (SPS), reaction rate.

\section{Pengembangan Lembar Penugasan Terstruktur Pada Materi Laju Reaksi Untuk Melatihkan Keterampilan Proses Sains}

\begin{abstract}
Abstrak
Penelitian ini bertujuan untuk mengetahui kelayakan lembar penugasan terstruktur untuk melatihkan peserta didik keterampilan proses sains (LPT-KPS) pada materi laju reaksi. Metode pengembangan yang digunakan dalam penelitian ini adalah Research and Development (R\&D). Pada penelitian ini hanya sampai pada tahap pengembangan, yaitu pada uji coba terbatas. Uji coba terbatas dilakukan kepada 15 peserta didik kelas XI dari SMAN 1 Arosbaya, SMAN 1 Kamal, dan SMAN 2 Bangkalan yang sudah mendapatkan materi laju reaksi. Penelitian ini diadakan pada bulan Desember 2020. Instrumen penelitian yang digunakan meliputi lembar telaah, lembar validasi, lembar angket respon peserta didik, dan lembar tes keterampilan proses sains. Hasil validitas yang diperoleh sebesar 93,3\% untuk validitas isi dan 91,4\% untuk validitas konstruk dengan kategori sangat valid. Respon peserta didik mengidentifikasikan bahwa LPT-KPS sangat praktis dengan persentase 100\%. Efektivitas memperoleh skor $\mathrm{N}$-gain sebesar 0,76 dengan kategori tinggi. Hal ini menandakan bahwa pengembangan LPT-KPS telah layak dan sesuai penggunaannya dalam proses pembelajaran.
\end{abstract}

Kata Kunci: lembar penugasan terstruktur (LPT), keterampilan proses sains (KPS), laju reaksi.

\section{INTRODUCTION}

Chemistry is always found in daily life and plays a substantial role in life. Chemistry builds on scientific processes, scientific attitudes, and scientific products. Students are looking forward to associating chemical concepts, principles, laws, and theories to solve the problems in their daily lives through chemistry learning (Permendikbud, 2013). Understanding of chemical concepts involves the study of macroscopic, submicroscopic, and symbolic aspects. Some chemistry teachers have difficulty integrating the three points of learning (Sastradewi et al., 2015) so that chemistry studies seem complex and abstract. As a result, most 


\section{Chemistry Education Practice, 4 (2), 2021 - 136}

Santoso, Suyono

students have difficulty understanding them in a short time.

When students are difficult to understand concepts in chemistry, their learning motivation would be decreasing. That was one of the causes why does the quality of education in Indonesia is still low. The results of Trends in International Mathematics and Science Study (TIMSS) showed that Indonesia's rank is $44^{\text {th }}$ out of 47 countries, with an average score of 397 (Hadi \& Novaliyosi, 2019). It also reinforced by the results of the Program for International Student Assessment (PISA) 2018, which shows that the average score of math, science, and reading in Indonesia is 382, ranking 71 out of 77 countries (OECD, 2018). The two things above show how low the level of education in Indonesia.

Improving the quality of education is one of the ways to solve the low grade of education in Indonesia. There are five ways to looking up the level of education, namely school leadership, proper standards, an effective system, personal motivation, and a conducive environment (Lutfi $\&$ Hidayah, 2018). Those aspects influence each other in terms of improving the grade of education. One of the factors is the proper standard, including the curriculum and learning tools used. This learning tool includes a syllabus, a Learning Implementation Plan, Student Worksheet, and a Structured Assignment Sheet (SAS).

Based on the Regulation of the Minister of Education and Culture (Permendikbud) Number 36 of 2018, students have a learning load in the form of structured assignments and independent activities, a maximum of $60 \%$ of the time face to face activities of the subjects concerned, in this case, chemistry subject. Therefore, this SAS needs to develop to complement the learning load of students under the Permendikbud Number 36 of 2018. SAS is used so that students not only understand the chemical concepts that have been taught but also can interpret these concepts in problems encountered in daily life. The teachers prepare SAS following basic competence. This SAS expected can improve the cognitive, affective, psychomotor of the students, also expected to train special skills such as science process skills.

Science process skills (SPS) are classified into basic process skills (observation, inference, measuring, communication, classification, and prediction skills) and integrated process skills (variable control skills, operational definition, hypothesis, data interpretation, experiments, and model formulation) (Aydin, 2013). In this study, the indicators of science process skills adopted from Kheng (2008), namely problem formulation, thinking framework, hypothesis formulation, research variables, operational definitions, experimental design, data collection and organizing stages, data analysis plans, practice making conclusion, and communication design exercise.

Science process skills need to be practice in the learning process. It is in line with Permendikbud Number 22 of 2016 concerning primary and secondary education content standards, which discusses the criteria for implementing the learning process that should encourage students to bring out observation skills to the invention that produce work based on problem-solving. Other demands that students must achieve during learning are skills acquired through observing, questioning, trying, reasoning, presenting, and creating in line with Permendikbud Number 21 of 2016. Meanwhile, the students' science process skills are not optimal yet. Nurliani et al. (2018) stated that the students' science process skills for communicating and concluding are $48,33 \%$ and $35 \%$ with low-skilled category. The study of Fitriana et al. (2019) showed that students have science process skills in the material reaction rates in high criteria of $9 \%, 35 \%$ medium criteria, and 56\% low criteria. The reason to train students' science process skills are skills demands in the $21^{\text {st }}$ century, and how to make them having such a capability to interpret chemical concepts when facing a problem in daily life, especially those related to reaction rates material.

Reaction rates material is the core material taught in class XI odd semester. Build upon the Regulation of the Minister of Education and Culture (Permendikbud) Number 37 of 2018, the basic competence (KD) expected from the reaction rates material is KD 3.6. Describe the factors that influence the reaction rates using collision theory and KD 4.7. Designing, conducting, concluding, and presenting the experimental outcome of the factors that influence the reaction rates and reaction order. Following this basic competence, students can observe and analyze a reaction rate phenomenon and can relate it to their actual situation so that the learning process becomes meaningful.

Based on the problems view over, know that there is no SAS as a varied learning tool to train students' science process skills. Therefore, 
researcher was interested in conducting a study entitled "Development of Structured Assignment Sheet in Reaction Rates Material to Train Science Process Skills."

\section{METHOD}

The research conducted is a type of development research by applying the Research and Development $(R \& D)$ research method. There are three phases in this research method, namely the preliminary study phase, the development phase, and the evaluation phase. Meanwhile, this research is only at the development phase, namely on limited testing. The function of limited testing is to specify the feasibility of the developed SAS-SPS by obtaining practicality and effectiveness values. In the preliminary study phase, the researcher analyzes the potential and existing problems. Then researcher collects various information that supports an initial study in the development of SAS-SPS. There are several stages in the development phase, namely product design with considering study from a chemistry lecturer, design validation, design revision, product trial (limited testing on 15 students from three schools), and obtain the final product in the form of SAS-SPS. The stages in this research presented in Figure 1.



Figure 1. Research Stages
Developed SAS-SPS tested on 15 students of XI grade from three schools who had received reaction rates material. This research conduct in December of the 2020/2021 school year at SMAN 1 Arosbaya, SMAN 1 Kamal, and SMAN 2 Bangkalan. Source of data obtain from chemistry lecturers, chemistry teachers, and 15 students from three schools through analysis. A chemistry lecturer conducts the study of the developed SAS-SPS. Two chemistry lecturers and one chemistry teacher carried out the validation of the developed SAS-SPS. Practicality data obtain from students' responses, and effectiveness data measured from the results of students' science process skills.

The research instruments include a study sheet, validation sheet, student response questionnaire, and science process skills test sheet. The results of the study were analyzed descriptively. The validation results of the development SAS-SPS were analyzed using quantitative description methods through percentages and obtained by comparing the scores obtained from all validators with the criteria score. The validator provides an assessment for each component in the developed SAS-SPS based on the Likert scale, presented in Table 1.

Table 1. Likert Scale

\begin{tabular}{cc}
\hline Scale & Criteria \\
\hline 1 & Very bad \\
2 & Bad \\
3 & Moderate \\
4 & Good \\
5 & Very good \\
\hline
\end{tabular}

Source: (Riduwan, 2015)

The formula used in the calculation to obtain a percentage, namely:

Percentage $(\%)=\frac{\Sigma \text { score obtained }}{\sum \text { score criteria }} \times 100 \%$

Score criteria $=$ highest score $\mathrm{x}$ number of aspects $x$ number of respondents. The interpretation of the results score is presented in Table 2.

Table 2. Validation Score Interpretation Criteria

\begin{tabular}{cc}
\hline Percentage (\%) & Criteria \\
\hline $0-20$ & Very invalid \\
$21-40$ & Invalid \\
$41-60$ & Quite.valid \\
$61-80$ & Valid \\
$81-100$ & Very-valid \\
\hline
\end{tabular}

Source: (Riduwan, 2015)

Based on the score interpretation criteria, the SAS-SPS developed is considered to be very 


\section{Chemistry Education Practice, 4 (2), 2021 - 138}

Santoso, Suyono

valid if the percentage output reaches $\geq 81 \%$, so it is suitable for use in the learning process.

The data on students' responses to the developed SAS-SPS were analyzed using quantitative descriptive methods on every aspect. The percentage of this data is obtained based on the Guttman scale calculation as in Table 3.

Table 3. Guttman Scale

\begin{tabular}{cc}
\hline Answer & Score \\
\hline Yes & 1 \\
No & 0 \\
\hline
\end{tabular}

Source: (Riduwan, 2015)

The formula used in the calculation to obtain a percentage, namely:

Percentage $(\%)=\frac{\Sigma \text { score obtained }}{\sum \text { score criteria }} \times 100 \%$

Score criteria $=$ highest score $\mathrm{x}$ number of aspects $x$ number of respondents. The interpretation of the results score is served in Table 4.

Table 4. Student Response Score Interpretation

\begin{tabular}{cc}
\hline Percentage (\%) & Criteria \\
\hline $0-20$ & Very impractical \\
$21-40$ & Impractical \\
$41-60$ & Quite practical \\
$61-80$ & Practical \\
$81-100$ & Very practical \\
\hline
\end{tabular}

Source: (Riduwan, 2015)

The practicality of developed SAS-SPS obtained from student response questionnaires analysis. Based on the score interpretation criteria, the developed SAS-SPS was considered to be very practical if the percentage results reach $\geq 81 \%$, so it is suitable for use in the learning process.

Data from the assessment of science process skills were analyzed using quantitative description methods. The analysis was carried out by looking at the students' initial and final scores from the pretest and posttest results using the $\mathrm{N}$ gain score. The formula used in the calculation to obtain the $\mathrm{N}$-gain score, namely:

$$
\mathrm{N}-\text { gain }=\frac{\text { posttest score }- \text { pretest score }}{\text { max score }- \text { pretest score }}
$$

The results of the $\mathrm{N}$-gain score obtained are divided into three criteria shown in Table 5.

Table 5. N-gain Score Criteria

\begin{tabular}{cc}
\hline N-gain Score & Criteria \\
\hline $\mathrm{g}<0,3$ & Low \\
$0,3 \leq \mathrm{g}<0,7$ & Medium \\
$\mathrm{g} \geq 0,7$ & High \\
\hline
\end{tabular}

Source: (Hake, 1998)

Students are declared complete if the $\mathrm{N}$-gain score reaches $\geq 0,7$ with high criteria, then the
SAS-SPS that trained on students can be said to be effective.

\section{RESULTS AND DISCUSSION}

The research entitled "Development of Structured Assignment Sheet in Reaction Rates Material to Train Science Process Skills" aims to develop and produce a Structured Assignment Sheet (SAS) that feasible to apply in the learning process. The feasibility of SAS-SPS not only viewed from content and construct validity but also tested on 15 students, which aim to obtain data of students' science process skills and student responses to SAS-SPS that developed. The indicators used in this research are from the adaptation of Kheng (2008), namely problem formulation, thinking framework, hypothesis formulation, research variables, operational definitions, experimental design, data collection and organizing stages, data analysis plans, practice making conclusion, and communication design exercise.

\section{Validity of SAS-SPS}

The data from the validation results of the development SAS-SPS were analyzed using quantitative description methods. Validation components are in the form of content validity and construct validity (Sugiyono, 2015). Two chemistry lecturers and one chemistry teacher at SMAN 2 Bangkalan carried out the validation of the developed SAS-SPS so that the validation results obtained shown in Table 6 .

Table 6. Validation Results

\begin{tabular}{ccc}
\hline Components & Percentage $\mathbf{( \% )}$ & Criteria \\
\hline Content & 93,3 & Very valid \\
Construct & 91,4 & Very valid \\
\hline
\end{tabular}

There are three components in the content validity, namely the SAS-SPS component, the material component of the SAS-SPS, and the suitability of the SAS-SPS with the science process skills indicator. The content validity of developed SAS-SPS reaches an average percentage of $93,3 \%$ with very valid criteria. It means that the SAS-SPS developed is appropriate in the learning process to trained science process skills.

The constructs validity contains components regarding the perception of the SPS indicator, the stages of the SPS indicator, and the consistency of SAS-SPS to train science process skills. The construct validity reaches an average percentage of $91,4 \%$ with very valid criteria. It means the developed SAS-SPS is suitable for 
providing to train science process skills using the indicators.

Several factors that caused SAS-SPS to be very valid are as follows. First, there are compatibility SAS-SPS components with instrument validity indicators and obtain the average score of validity in very valid criteria. Second, validity aspects of SAS-SPS have been fulfilled, such as content validity and constructs validity (Ningsih et al., 2015). The fulfillment of content validity is due to the developed SAS-SPS under the appropriate theories used as a guideline in the SAS-SPS development. Meanwhile, the fulfillment constructs validity is due to the SASSPS developed has paid attention to linkages between components SAS-SPS with the SPS indicators to be trained and the phenomena related to the concept of the reaction rate material. Third, there is consistency between sections SASSPS developed from the urgency of SAS-SPS for students, indicators of SPS, and the phenomena used in SAS-SPS.

Based on the validation results, both content validity and constructs validity reach an average percentage $\geq$ of $81 \%$ with very valid criteria. The development of SAS-SPS in terms of validity shows that it is very feasible for use in the learning process on reaction rates material to train science process skills.

\section{Practicality of SAS-SPS}

The practicality of the developed SAS-SPS was obtained through student response questionnaire data and analyzed using quantitative descriptive methods. There are eleven questions in the questionnaire and given to 15 students. All of the questions related to the indicator of science process skills form the adaptation of Kheng (2008). The student response questionnaire results obtained shown in Table 7.

Table 7. Student Response Questionnaire Results

\begin{tabular}{ccc}
\hline Name & Percentage $(\%)$ & Criteria \\
\hline ISR & 100 & Very practical \\
AJS & 100 & Very practical \\
MRF & 100 & Very practical \\
AAR & 100 & Very practical \\
NR & 100 & Very practical \\
H & 100 & Very practical \\
FF & 100 & Very practical \\
PKW & 100 & Very practical \\
RA & 100 & Very practical \\
SP & 100 & Very practical \\
DN & 100 & Very practical \\
PDF & 100 & Very practical \\
RHR & 100 & Very practical \\
\hline
\end{tabular}

\begin{tabular}{ccc}
\hline HOW & 100 & Very practical \\
DPW & 100 & Very practical \\
\hline A total of & 15 students & agreed that the
\end{tabular}
developed SAS-SPS was able to provide direction to students to write problem formulation in an interrogative sentence which contains manipulation variables and response variables; to write thinking framework in the form of a narrative as a guide to solving research problems and formulating hypothesis; to write hypothesis formulation with the formula "If..., then..." and adjusted to the problem formulation posed; to write research variables contains manipulation variables, control variables, and response variables; to write operational definitions correctly and make specifications for certain scientific terms; to write experimental design coherently to solve problem formulation posed; to write data collection and organizing stages correctly; to write the analysis stages that will be carried out coherently and in accordance with the problem formulation posed; to practice making conclusion correctly; and to write presentation design to communicate the results of solving the problem that have been done. In addition, all respondents consisting of 15 students also agreed that the developed SAS-SPS able to facilitate students in practicing science process skills.

Based on the average student response questionnaire results obtained were $100 \%$ of students responding positively with very practical criteria. The results stated that students agreed that developed SAS-SPS facilitate them in practicing science process skills, and students could more understand the reaction rates material related to phenomena in daily life.

\section{The Effectiveness of SAS-SPS}

The effectiveness data of SAS-SPS was obtained from 15 students from SMAN 1 Arosbaya, SMAN 1 Kamal, and SMAN 2 Bangkalan. Then the data were analyzed by comparing the students' initial and final scores from the pretest and posttest results. Both pretest and posttest contain indicators of science process skills that are associated with phenomena in daily life. The average data from pretest and posttest were analyzed using $\mathrm{N}$-gain and presented in Table 8.

Table 8. N-gain Results

\begin{tabular}{cccc}
\hline $\begin{array}{c}\bar{x} \\
\text { Pretest }\end{array}$ & $\bar{x}$ Posttest & N-gain & Criteria \\
\hline 22 & 81 & 0.76 & High \\
\hline Based & on & the & pretest \\
\hline
\end{tabular}

students had difficulty working on indicators of 


\section{Chemistry Education Practice, 4 (2), 2021 - 140}

Santoso, Suyono

science process skills correctly. It indicated from the average pretest score results, which reach 22 . However, after being given SAS-SPS, there is an increase in the science process skills of all students. As a result, the average posttest score reaches 81 .

Based on the posttest results, the problem formulation stage shows that there are still four students whose problem formulation is incorrect because it only contains the response variable. At the thinking framework stage, two students make inappropriate thinking framework with the problem formulation, and 12 students make appropriate thinking framework with the problem formulation even though it is not coherent yet. At the hypothesis formulation stage, there one student whose hypothesis formulation is inappropriate with the problem formulation. At the determining research variables stage, the majority of students can determine three to all of the research variables correctly, but three students only determine half of the research variables correctly. At the operational definition stage, there are still seven students who only able to determine half of the operational definitions used in the experiment correctly. At the experimental design stage, all students can make an experimental design that is appropriate and coherent with the existing phenomena. At the data collection and organizing stages, still, two students whose data are unsuitable with the problem formulation and the experimental design. At the phase of data analysis plans, there are still two students whose data analysis plan is inappropriate with the problem formulation. At the stage of practice making solutions, almost all students have been able to make an appropriate conclusion with the problem formulation, but there is still one student whose conclusion is inappropriate with the problem formulation. At the last stage, all the students can make appropriate communication designs, including the media and points to be presented.

The average students' science process skills reach an $\mathrm{N}$-gain score of 0,76 with high criteria. These two students get N-gain score on moderate criteria, with $\mathrm{N}$-gain scores of 0,58 and 0,63 . Thus, the developed SAS-SPS can be said to be effective for training students' science process skills on the reaction rates material.

Several factors that causing SAS-SPS to be effective are as follows. First, the SAS-SPS developed is designed accordingly with the demands of the curriculum (Ningsih et al., 2015). Second, learning accompanied by phenomena in daily life can increase the attractiveness of students to learn and can develop students' science process skills. Third, the presentation of SAS-SPS developed are structured (Sastradewi et al., 2015) and contains directions on each SPS indicator.

\section{CONCLUSION}

Based on the results and discussion that has been done, it can be concluded that a structured assignment sheet in reaction rates material to train students' science process skills is feasible. The validity obtains a percentage of content validity of $93,3 \%$ and constructs validity of $91,4 \%$, both of them have very valid criteria. It shows that the developed SAS-SPS is very valid. The results of the student response questionnaire show a percentage of $100 \%$. It indicates that the developed SAS-SPS is very practical. The results of the science process skills test get an $\mathrm{N}$-gain score of 0,76 with high criteria. It shows that the developed SAS-SPS is effective.

\section{REFERENCES}

Aydin, A. (2013). Representation of Science Process Skills in The Chemistry Curricula for Grades 10, 11 and 12 / Turkey. International Journal of Education and Practice, 1(5), 51-63.

Fitriana, Kurniawati, Y., \& Utami, L. (2019). Analisis Keterampilan Proses Sains Peserta Didik Pada Materi Laju Reaksi Melalui Model Pembelajaran Bounded Inquiry Laboratory. JTK (Jurnal Tadris Kimiya), 4(2), 226-236.

Hadi, S., \& Novaliyosi. (2019). TIMSS Indonesia (Trends in International Mathematics and Science Study). Prosiding Seminar Nasional \& Call For Papers Program Studi Magister Pendidikan Matematika Universitas Siliwangi, 562-569.

Hake, R. R. (1998). Interactive-Engagement Versus Traditional Methods: A sixThousand-Student Survey of Mechanics Test Data for Introductory Physics Courses. American Journal of Physics, 66(1), 64-74.

Kheng, Y. (2008). Longman Science Process Skill. Selangor Darul Ehsan: Pearson Malaysia.

Lutfi, A., \& Hidayah, R. (2018). Manajemen Sekolah. Surabaya: UNESA University Press.

Ningsih, N. L. ., Karyasa, I. W., \& Suardana, I. 


\section{Chemistry Education Practice, 4 (2), 2021 - 141}

Santoso, Suyono

N. (2015). Pengembangan Perangkat Pembelajaran Kimia Dengan Setting Sains Teknologi Masyarakat (Stm) Untuk Meningkatkan Keterampilan Proses Sains Dan Pemahaman Konsep Kimia Siswa. Jurnal Pendidikan Dan Pembelajaran IPA Indonesia, 5(1), 1-11.

Nurliani, Sartika, R. P., \& Hadi, L. (2018).

Deskripsi Keterampilan Proses Sains Siswa Kelas XI IPA SMA Negeri 2 Sungai Raya pada Materi Asam Basa. Jurnal Pendidikan Dan Pembelajaran Khatulistiwa, 7(7), 1-14.

OECD. (2018). What 15-Year-Old Students in Indonesia Know and Can Do. Programme for International Student Assessment (PISA) Result from PISA 2018, 1-10.

Permendikbud. (2013). Peraturan Menteri Pendidikan dan Kebudayaan Republik Indonesia Nomor 54 Tahun 2013 Tentang Standar Kompetensi Lulusan Pendidikan Dasar dan Menengah. Jakarta: Kementrian Pendidikan dan Kebudayaan.

Permendikbud. (2016a). Peraturan Menteri Pendidikan dan Kebudayaan Republik Indonesia Nomor 21 Tahun 2016 tentang Standar Isi Pendidikan Dasar dan Menengah. Jakarta: Kementrian Pendidikan dan Kebudayaan.

Permendikbud. (2016b). Peraturan Menteri Pendidikan dan Kebudayaan Republik Indonesia Nomor 22 Tahun 2016 tentang Standar Isi Pendidikan Dasar dan Menengah. Jakarta: Kementrian Pendidikan dan Kebudayaan.

Permendikbud. (2018a). Peraturan Menteri Pendidikan dan Kebudayaan Republik Indonesia Nomor 36 Tahun 2018 tentang Kurikulum 2013 Sekolah Menengah Atas/Madrasah Aliyah. Jakarta: Kementrian Pendidikan dan Kebudayaan. Permendikbud. (2018b). Peraturan Menteri Pendidikan dan Kebudayaan Republik Indonesia Nomor 37 Tahun 2016 tentang Kompetensi Inti dan Kompetensi Dasar Kimia SMA/MA. Jakarta: Kementrian Pendidikan dan Kebudayaan.

Riduwan. (2015). Skala Pengukuran VariabelVariabel Penelitian. Bandung: Alfabeta. Sastradewi, P. F., Sadia, I. W., \& Karyasa, I. W. (2015). Pengembangan Perangkat Pembelajaran Kimia Yang Menerapkan Model Problem Based Learning ( $\mathrm{Pbl}$ ) Untuk Meningkatkan Pemahaman Konsep Siswa. Jurnal Pendidikan Dan
Pembelajaran IPA Indonesia, 5(1), 1-12. Sugiyono. (2015). Metode Penelitian

Kuantitatif, Kualitatif, dan $R \& D$. Bandung: Alfabeta. 